\begin{abstract}
Iranica
Abstracta Iranica Revue bibliographique pour le domaine irano-aryen

Volume 32-33 | 2013

Comptes rendus des publications de 2009-2010
\end{abstract}

\title{
Alexandre Tourovets. Le motif de la danseuse dans l'orfèvrerie sassanide
}

\section{Rémy Boucharlat}

\section{(2) OpenEdition}

1 Journals

\section{Édition électronique}

URL : http://journals.openedition.org/abstractairanica/40584

DOI : 10.4000/abstractairanica.40584

ISSN : 1961-960X

Éditeur :

CNRS (UMR 7528 Mondes iraniens et indiens), Éditions de l'IFRI

\section{Édition imprimée}

Date de publication : 1 décembre 2013

ISSN : 0240-8910

\section{Référence électronique}

Rémy Boucharlat, «Alexandre Tourovets. Le motif de la danseuse dans l'orfèvrerie sassanide ", Abstracta Iranica [En ligne], Volume 32-33 | 2013, document 204, mis en ligne le 01 juillet 2016, consulté le 03 octobre 2020. URL : http://journals.openedition.org/abstractairanica/40584 ; DOI : https://doi.org/ 10.4000/abstractairanica.40584

Ce document a été généré automatiquement le 3 octobre 2020.

Tous droits réservés 


\title{
Alexandre Tourovets. Le motif de la danseuse dans l'orfèvrerie sassanide
}

\author{
Rémy Boucharlat
}

\section{RÉFÉRENCE}

Alexandre Tourovets. « Le motif de la danseuse dans l'orfèvrerie sassanide », in : Ch. Cannuyer, A. Degrève et R. Gérard, éds., Vin, bière et ivresse dans les civilisations orientales, Entre plaisir et interdit, René Lebrun in honorem. Louvain-la-Neuve, S.B.É.OB.G.O.S., 2009, p. 65-88, 16 fig. (Acta Orientalia Belgica XXII)

1 L'A. ne résout pas la question de l'identité de la danseuse fréquemment représentée sur des vases en métal, faute de données nouvelles depuis des décennies. Ses remarques sur l'absence complète de temples à Anahita sont intéressantes (malgré les hypothèses sur le monument semi souterrain de Bishapur). En revanche, écrire qu'on ne connaît aucun temple dit du feu sassanide en Iran est - heureusement - erroné depuis des années (voir entre autres $n^{\circ} 178$ et 189), exemples de temples ordinaires, sans oublier Takht-i Solaiman connu depuis plus de 40 ans.

\section{AUTEURS}

RÉMY BOUCHARLAT

CNRS/Lyon 